BIS WORKING PAPERS

No. 84 - January 2000

\title{
WHAT HAVE WE LEARNED FROM RECENT FINANCIAL CRISES AND POLICY RESPONSES?
}

by

William R White

BANK FOR INTERNATIONAL SETTLEMENTS

Monetary and Economic Department

Basel, Switzerland 
BIS Working Papers are written by members of the Monetary and Economic Department of the Bank for International Settlements, and from time to time by other economists, and are published by the Bank. The papers are on subjects of topical interest and are technical in character. The views expressed in them are those of their authors and not necessarily the views of the BIS.

Copies of publications are available from:

Bank for International Settlements

Information, Press \& Library Services

$\mathrm{CH}-4002$ Basel, Switzerland

Fax: +41 61 / 2809100 and +4161/2808100

This publication is available on the BIS website (www.bis.org).

(C) Bank for International Settlements 2000.

All rights reserved. Brief excerpts may be reproduced or translated provided the source is stated. 


\title{
BIS WORKING PAPERS
}

No. 84 - January 2000

\section{WHAT HAVE WE LEARNED FROM RECENT FINANCIAL CRISES AND POLICY RESPONSES?}

\author{
by
}

\author{
William R White
}

\begin{abstract}
This paper draws some policy lessons from recent financial crises. Three forms of financial instability are distinguished: short-term volatility, medium-term misalignments including excessive international capital flows, and contagion across both markets and countries. Some underlying factors contributing to each form of instability are identified and specific public policies are recommended to help alleviate each.

Attention is also focused on recent changes in the processes for developing and implementing incremental policies to improve the international financial system. Finally, it is concluded that it would not be appropriate (at this time at least) to try to establish an international superregulator.
\end{abstract}





\section{Contents}

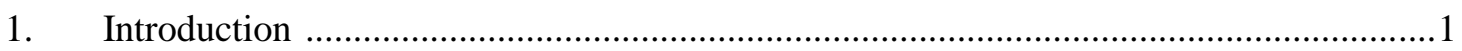

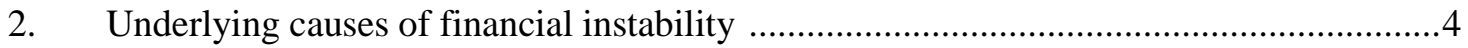

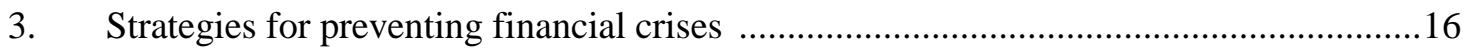

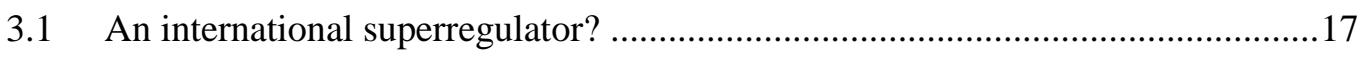

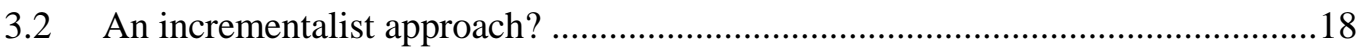

3.2.1 Issues of process affecting international financial stability ......................18

3.2.2 Issues of substance affecting international financial stability ...................21

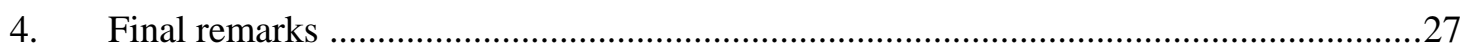

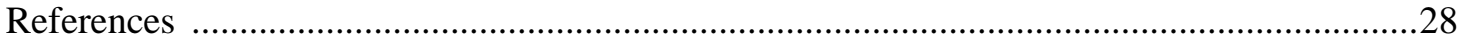





\section{Introduction ${ }^{1}$}

Both the frequency and severity of international financial crises seem to have been rising over the last twenty years or so, in most cases associated with rising internal or external debt levels that have eventually proved difficult to either fund or service. Moreover, financial crises have increasingly led to severe economic disruption, increases in unemployment and even a return to poverty for many in some emerging markets. These developments have given increased impetus to the search for solutions and to learning from recent experiences. Further urgency arises from the recognition that a number of global economic imbalances remain unresolved; for example the trade imbalances among the G3 and excess supply in a wide number of industries producing tradable goods. The fact that measured inflation is already quite low in most industrial countries, and that macroeconomic policy levers may also be constrained (either by the zero interest rate $\operatorname{limit}^{2}$ or the perceived exigencies of medium term fiscal adjustment), also implies that future financial crises would be best avoided.

In approaching the problem of recurring financial crises, attention could properly be paid to three different kinds of issues; crisis prevention, crisis management and crisis resolution. Indeed, in each area, the gravity of recent developments have increasingly led commentators to suggest "radical" as well as "incremental" solutions to perceived problems. With respect to crisis prevention, the proposals of Eatwell and Taylor (1998) to establish a global superregulator come to mind. As for crisis management, recent suggestions made by George Soros (1998), Stanley Fischer (1999) and Jeff Garten (1998) can be mentioned. And finally, in the area of crisis resolution, Sebastian Edwards (1998) has suggested a global restructuring agency, while Steven Radelet and Jeff Sachs (1997) have proposed international bankruptcy procedures analogous to those of Chapter 11 in the United States.

This paper will focus principally on issues pertinent to crisis prevention. This reflects the fact that such concerns constitute the principal preoccupation of the three Standing Committees of national experts which meet regularly at the Bank for International Settlements. ${ }^{3}$ The policy conclusions to be drawn from recent experiences have both a microeconomic and a macroeconomic dimension, but in both respects incrementalist solutions seem more appropriate and realistic than a radical overhaul of the international financial system.

1 Some of the Tables and Charts in this paper have been updated from Bank for International Settlements (1998a and 1999b). Parts of this revised paper provided the basis for presentations made at the conference "Coping with financial crises in developing and transition countries: regulatory and supervisory challenges in a new era of global finance" organised by the Forum on Debt and Development (Amsterdam, 16-17 March 1998) and the conference "Lessons from Recent Global Financial Crises" cosponsored by the BIS and the Federal Reserve Bank of Chicago (Chicago, 30 September-2 October 1999).

2 For a recent discussion of such issues, see DeLong (1999) and Bank for International Settlements (1999b) pp.77-81.

3 The Basel Committee on Banking Supervision: (BCBS); The Committee on the Global Financial System (CGFS, formerly the Euro-Currency Standing Committee (ECSC)) and the Committee on Payments and Settlement Systems (CPSS). 
Some specific reasons are presented below for believing that it is premature, at best, to establish a global superregulator to promote crisis prevention world wide. More generally, it can be argued that our current knowledge about both the causes and consequences of financial crises is inadequate to support anything but piecemeal policy solutions. With respect to ignorance about causes, it is instructive to note that neither Mexico nor the South-East Asian countries were widely viewed as vulnerable before their respective crises began. In the event, commonly held beliefs that responsible fiscal policies and high domestic savings rates would suffice to prevent financial crises proved sadly wrong. As to ignorance about consequences, Chart 1 shows the quite extraordinary extent to which forecasters missed the severity of the Asian downturn as well as the more recent upturn. ${ }^{4}$

\section{Chart 1}

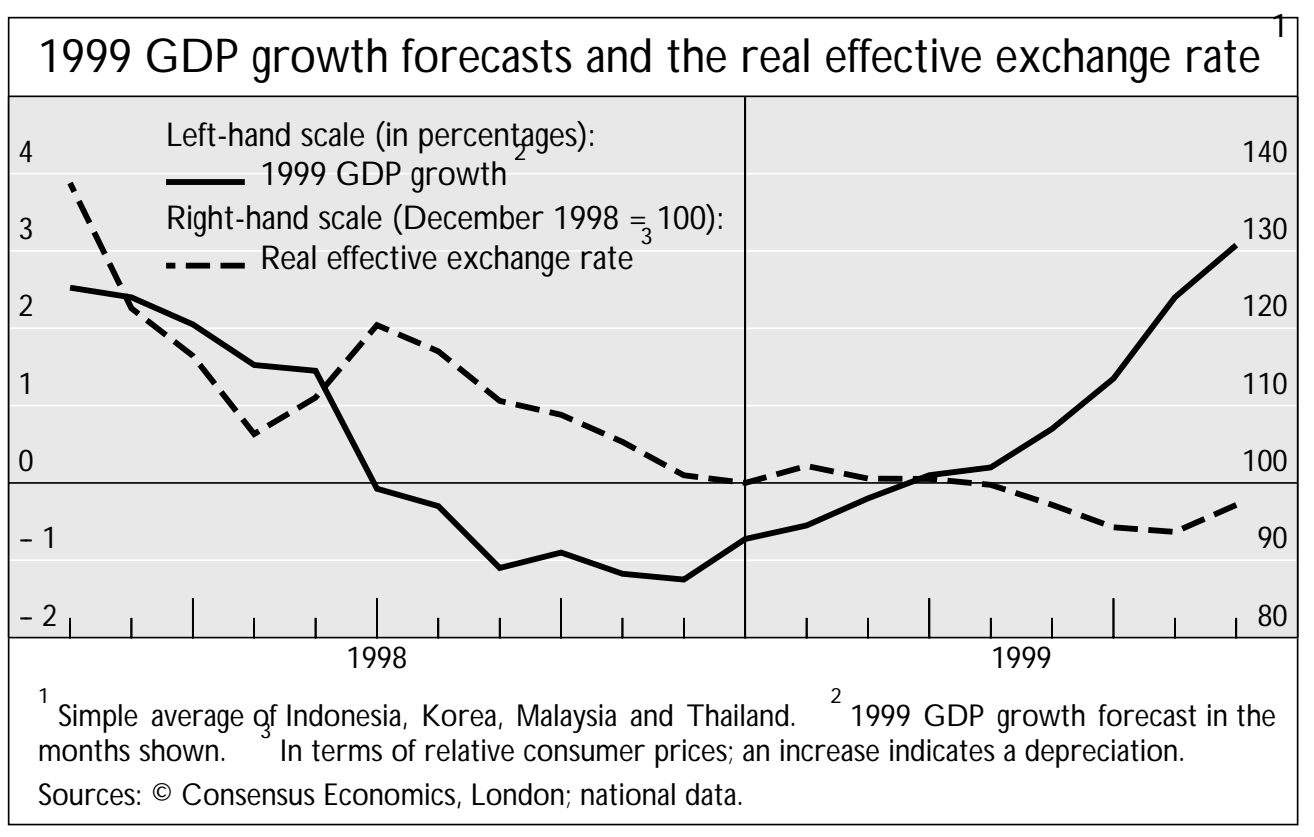

A further important consideration which must guide the search for practical solutions is that the character of recent financial crises has differed in significant ways. Among many other implications, this fact is pertinent to the issue of the usefulness of bond contracts including (say) sharing and majority voting clauses. It is notable that the emerging market debt crisis of the 1980s essentially involved a limited number of banks as creditors with sovereigns as the indebted parties; in this case, such clauses would have been of little relevance. In contrast, in the Mexican crisis of 1994-95, while a sovereign was again the indebted party, most of the lending had been done through disintermediated markets by tens of thousands of different lenders. In East Asia in 1997 and subsequently, a relatively small number of banks were again the dominant lenders (though securities issuance was increasingly significant) but lending was essentially to a wide range of private sector entities, both banks and non-

4 For an analysis of the successes and failures of forecasters in the industrial countries see Andersen (1997). Actual outturns for real GDP growth in 1999 in both Japan and the United States have also differed sharply from consensus forecasts made at the beginning of the year. 
banks. And although not yet seen in the post-war period, crises could also be envisaged involving very large numbers of both borrowers and lenders interacting almost exclusively through disintermediated markets as they did in the 1920's. The central point is that measures to prevent the recurrence of the last crisis may not in fact prevent future crises since crises can arise and propagate themselves in very different ways. ${ }^{5}$

While recognising that differences in circumstances do matter in the search for solutions, an important underlying fact can still be identified; namely, the growing reliance on market-based financing processes as opposed to more traditional intermediated finance. Salient features of this trend include the sharp rise in securities issues by emerging markets, the growing use of securitisation in the financial markets of industrial countries and the virtual explosion in the use of derivative instruments (mostly traded in OTC markets). Moreover, international financial markets are increasingly integrated in complex ways, global in scope, and are changing rapidly with respect to the participants, instruments in use and the technological channels through which financial services are being provided.

On the basis of these observations, and the assumption that they will continue, ${ }^{6}$ a number of principles might be identified (White 1998a) to guide the choice of a strategy for promoting financial stability. First, measures to strengthen the system must be comprehensive and must cover each of the main pillars of the international financial system: institutions, markets and infrastructure. Second, policymakers and regulators must rely increasingly on market-led processes to provide the discipline required to encourage prudent and stabilising behaviour. Third, recognising the limitations of markets (Bubbles do occur! Market failures do happen!), the complementary activities of regulators and supervisors will continue to be needed to reinforce market discipline. And finally, whatever measures are taken to strengthen the financial system, these measures must recognise its international dimension. If level playing-fields are to be encouraged and regulatory arbitrage avoided, these measures will increasingly have to be the result of international negotiations and agreements.

The events of the last 18 months, in particular the spectacular fallout from the Russian crisis and the events surrounding the devaluation of the Brazilian real, provide no cause to question fundamentally any of these conclusions. However, they do serve to strengthen the belief that the dynamics of market behaviour ought to be a source of increasing concern to policymakers and market participants themselves. ${ }^{7}$ At present, it is not clear who is responsible for the regulatory oversight of markets and

It might also be added that the Mexican crisis of 1995 had its roots in domestic overconsumption whereas the Asian crisis was in part the product of extremely high levels of domestic investment. This fact would seem likely to have an important effect on the recovery path.

6 This is not equivalent to a statement that market based financial systems are likely to be more stable than those based on intermediated credit and relationship banking. Perhaps the only thing that is clear is that financial systems having both strong markets and strong intermediaries are likely to be more stable than systems based on only one pillar. This is the essential reasoning behind current efforts to develop bond markets in Asia.

7 For a more detailed analysis of these events see BIS (1999b), Chapters III and V. 
the credit excesses to which they might contribute. What also seems confirmed by recent experience is the strong interrelationships between macroeconomic instability and financial instability. To make this point more clearly, any strategy for dealing with the instability of financial markets must investigate the extent to which that instability has its roots in macroeconomic phenomena, in particular an excessive rate of growth of credit, and in the choice of an inappropriate exchange rate regime.

This paper begins with the recognition that there are different kinds of financial instability and therefore different kinds of financial crises. It then proceeds to question how international markets might have contributed to these different kinds of instability and goes on to consider possible policy responses to the specific problems identified. In this last regard, some emphasis is put on arguments for and against establishing some form of international superregulator, as well as some of the practical problems inherent in implementing those policy measures that do seem to have some merit. Little mention is made, either of the domestic roots of recent crises in emerging markets, or the need for stronger domestic financial systems based on better infrastructure, accounting, governance, legal and payments systems and supervision. These truths are taken as self evident.

\section{Underlying causes of financial instability}

In light of recent developments in international financial markets, concerns have grown that such markets may themselves be increasingly important sources of financial instability of different sorts. One possibility is that there may now be greater short-run volatility in asset price movements. Another possibility is the enhanced likelihood of longer-term misalignment in asset prices, where misalignments are thought of as deviations from longer-term equilibrium prices. The third possibility is that international financial markets enhance the likelihood of contagion across previously separated markets. In fact, there are grounds for believing that all three problems may be of greater significance now than previously. ${ }^{8}$

While there is a popular perception that the short-run volatility of asset prices is now greater than it used to be, by some empirical measures this is not in fact the case. If one considers the standard deviations of monthly price changes for a wide range of assets in industrial countries, there was no clearly discernible trend in the twenty-year period ending in $1996 .^{9}$ This having been said, there does seem to be supportive evidence for this hypothesis in daily data drawn from financial markets in emerging countries (Table 1) and from more recent data in industrial countries ${ }^{10}$ as well (Chart 2).

8 These distinctions are conceptually useful, but of course there are interrelationships in practice. Murray et al. (1996) demonstrates that the sharpest short run movements in financial markets often occur after a long period of gradual misalignment from fundamentals.

9 This stylised fact emerges from BIS (1996). Note, however, that the early part of this period contained the marked turbulence of the 1970s.

10 See BIS (forthcoming): "International financial markets and the implications for monetary and financial stability", BIS Conference Papers, No. 8. 
Moreover, it is a fact that standard deviations are themselves a form of average which may hide occasional large price movements capable of inflicting serious damage on individual agents and even potentially the financial system itself.

Table 1

Daily mean and volatility of emerging market bond spreads*

\begin{tabular}{l|c|c|c|c|c|c}
\hline \multirow{2}{*}{} & \multicolumn{2}{|c|}{ January 1997-June 1997 } & \multicolumn{2}{l|}{ July 1997-June 1998 } & \multicolumn{2}{l}{ July 1998-June 1999 } \\
\cline { 2 - 7 } & Mean & $\begin{array}{l}\text { Standard } \\
\text { deviation }\end{array}$ & Mean & $\begin{array}{l}\text { Standard } \\
\text { deviation }\end{array}$ & Mean & $\begin{array}{l}\text { Standard } \\
\text { deviation }\end{array}$ \\
\cline { 2 - 7 } & \multicolumn{7}{|c|}{ in basis points } \\
\hline Asia & 104 & 7 & 268 & 102 & 497 & 137 \\
Latin America & - & - & 289 & 67 & 638 & 158 \\
Eastern Europe & - & - & 90 & 20 & 127 & 27 \\
\hline
\end{tabular}

* Over benchmark US Treasury bonds.

So-called "fat tail" events can be perceived in the 1987 stock market crash, the bond market collapses of 1958 and 1994, the sharp fluctuations in the yen/dollar rate in mid-1995 and the events surrounding the Russian debt moratorium in August 1998 allied with the subsequent difficulties of Long-Term Capital Management. The chain of events in this last case seems to have been large losses by heavily leveraged investors in Russian paper, ${ }^{11}$ followed by recognition that the credit standing of those

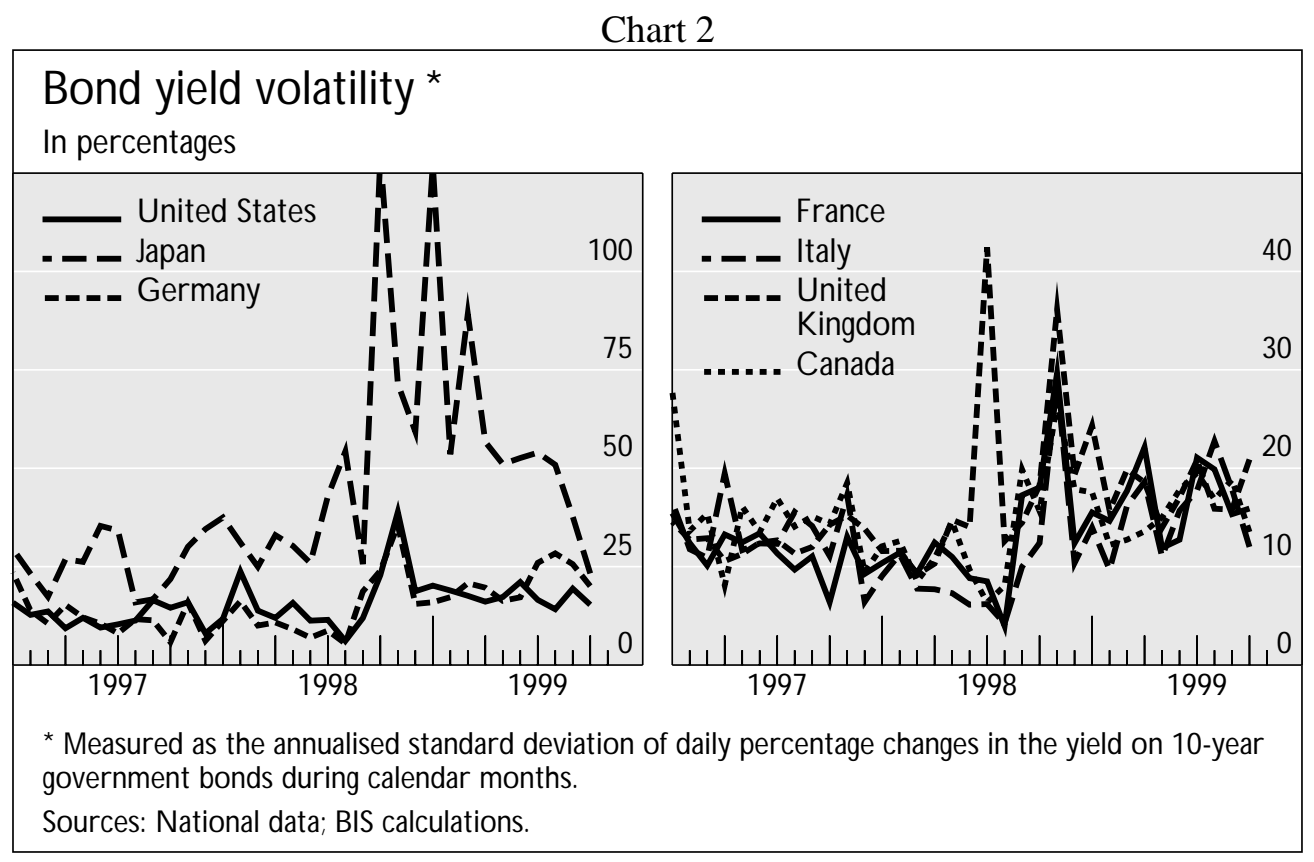

11 For a comprehensive evaluation of this whole episode, see BIS: CGFS (1999b). Some would say the chain started earlier with the closing on July 6 of Salomon Brothers "relative value arbitrage" desk and the first ever losses suffered by LTCM in June and July. These developments called into question the continuing profitability of this kind of trading and also the sustainability of the narrower spreads which it had generated. 
investors was potentially seriously compromised. As credit spreads widened, due both to falling government yields and rising rates on lower quality paper, many lenders withdrew from the markets leading to liquidity shortages (see Charts 3 and 4). Moreover, such tendencies were further exacerbated by the fact that heavily leveraged investors had in many markets previously played the role of market maker. ${ }^{12}$

Chart 3

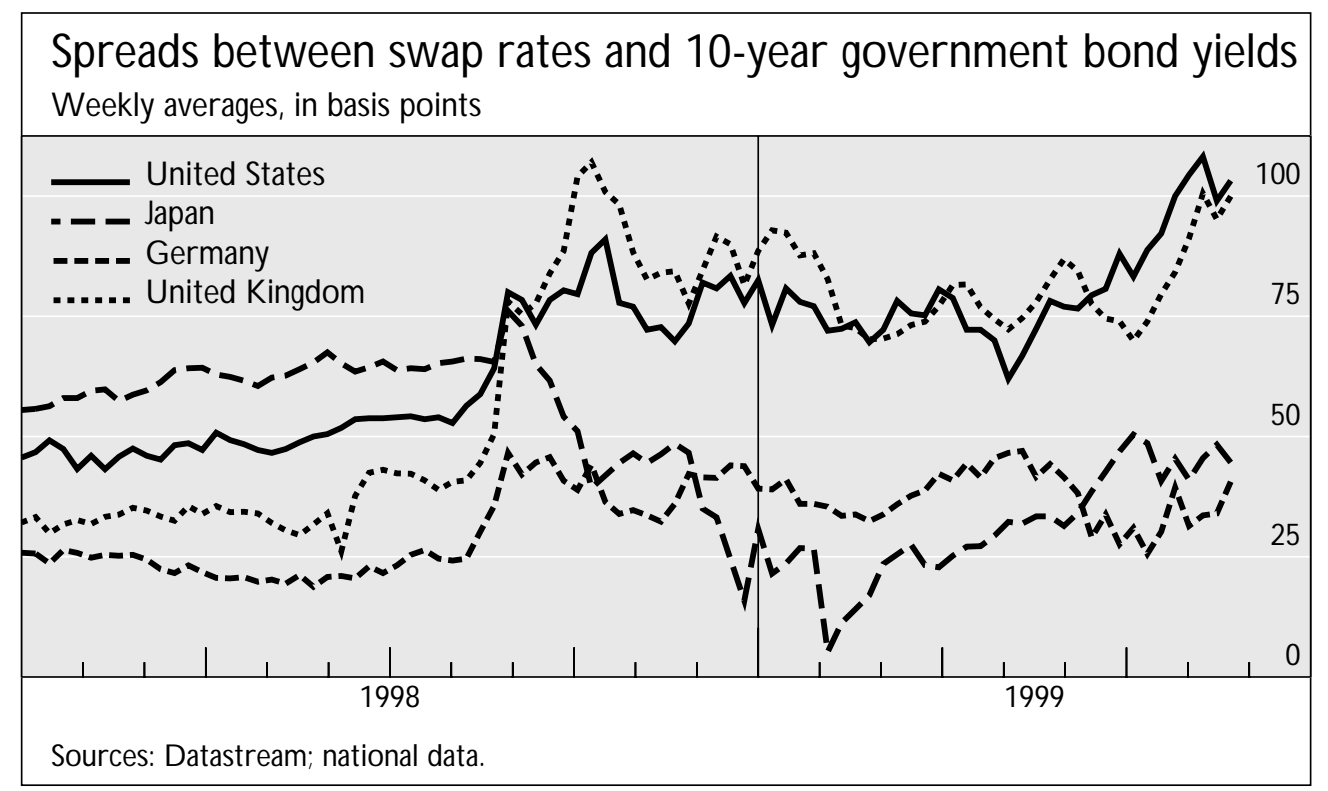

Chart 4

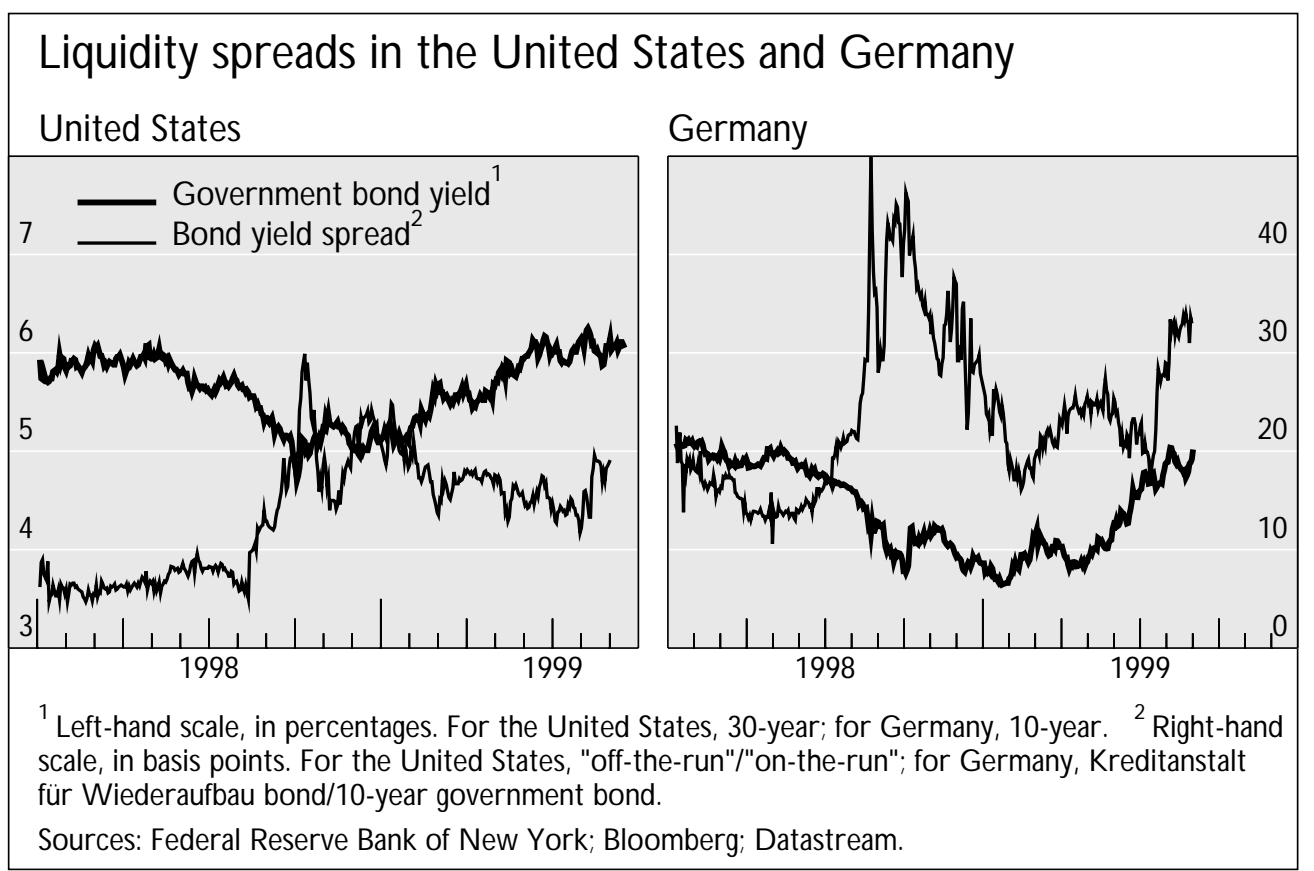

12 Following these events, liquidity premia in virtually all financial markets remained high and the correlation between movements in these premia increased. This may have reflected the exit of highly leveraged investors as market makers. See Morgan Stanley (1999, August 18). 
This combination of events also seems to have engendered a more wide ranging re-evaluation by international investors of the likelihood of future sovereign bailouts, their assessment of fundamentals in many markets, and even the usefulness of their own risk management strategies. The upshot of all this was that the turmoil spread far beyond those markets initially affected. More technical factors also contributed to this outcome. For example, Chart 5 shows the massive swings in perceptions about the future value of the yen/dollar rate in early October of 1998 with the spot rate moving almost $7 \%$ on one day alone. Confronted with losses arising from the events described above, as well as calls for margin as the value of collateral fell, investors who had borrowed cheaply in yen were forced to close out their positions, putting sudden and violent upward pressure on the value of the yen.

\section{Chart 5}

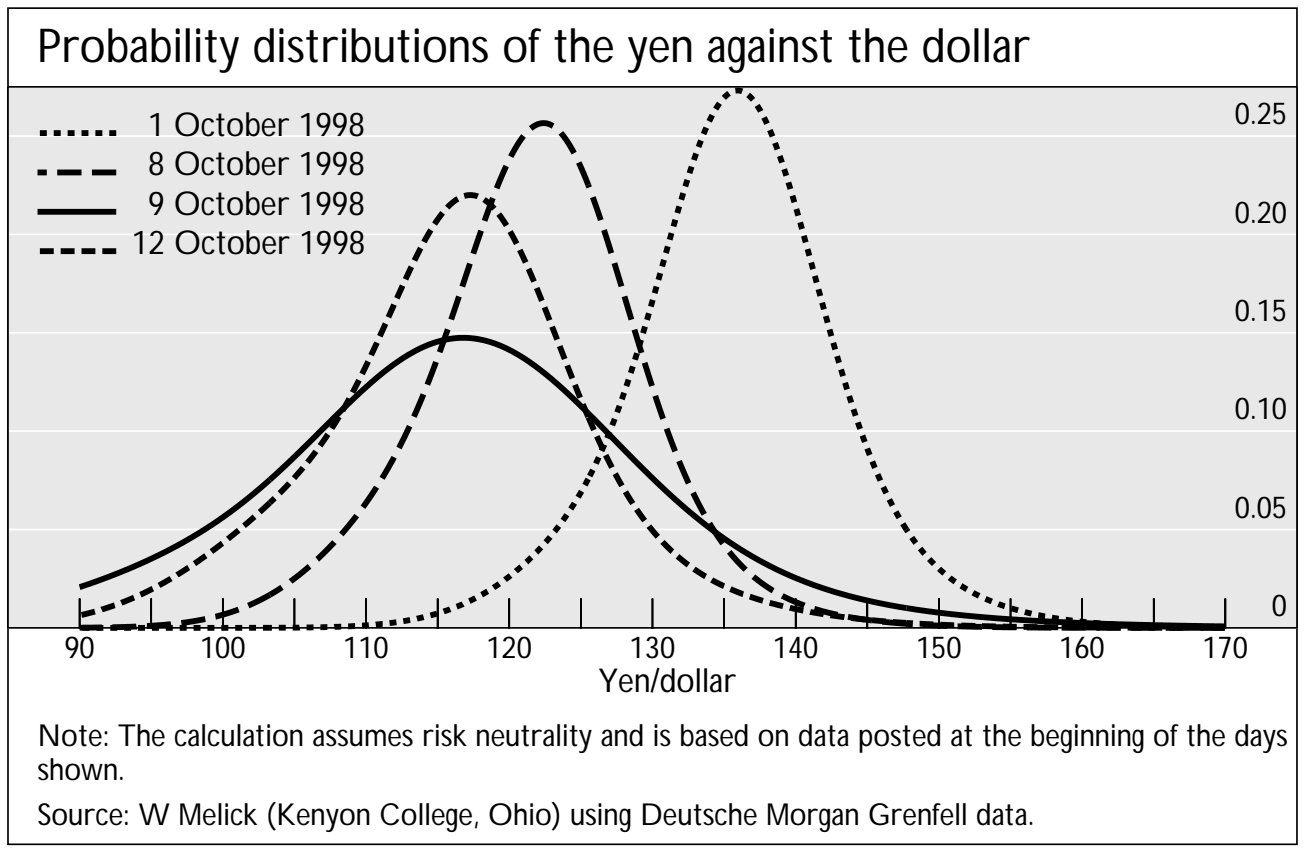

As is now well known, concerns about the implications of a disorderly winding-down of the book of Long-Term Capital Management were so great that the Federal Reserve Bank of New York felt it prudent to organise a private sector support operation to ensure this did not happen. This development was consistent with a wide spread belief that the company was either too big or too complicated to fail or both. These events would seem consistent with modern financial markets having the capacity to sharply increase short-term price volatility. While it may be of only small comfort, it is worth noting that the infrastructure supporting the international financial system, in particular facilities for clearing and settlement, continued to operate effectively throughout this period of unusual stress.

Assessing whether modern financial markets have become more prone to generate misalignments and bubbles (deviations of asset prices from longer run equilibrium prices) is even more difficult since the concept of an equilibrium price is itself very fuzzy. A theoretical starting point might be the Wicksellian concept of a discrepancy between the market rate of interest and the "natural" rate of 
interest but this is of little practical use. A further complication arises from interaction between the behaviour of market participants and the actions of the official sector. As seen in Chart 6, periods of declining policy interest rates in the major industrial countries do seem to be correlated with periods when investors seemed to become relatively less risk-adverse. ${ }^{13}$ Should bubbles occur in consequence, it becomes difficult to disentangle the relative contribution of each source.

Chart 6

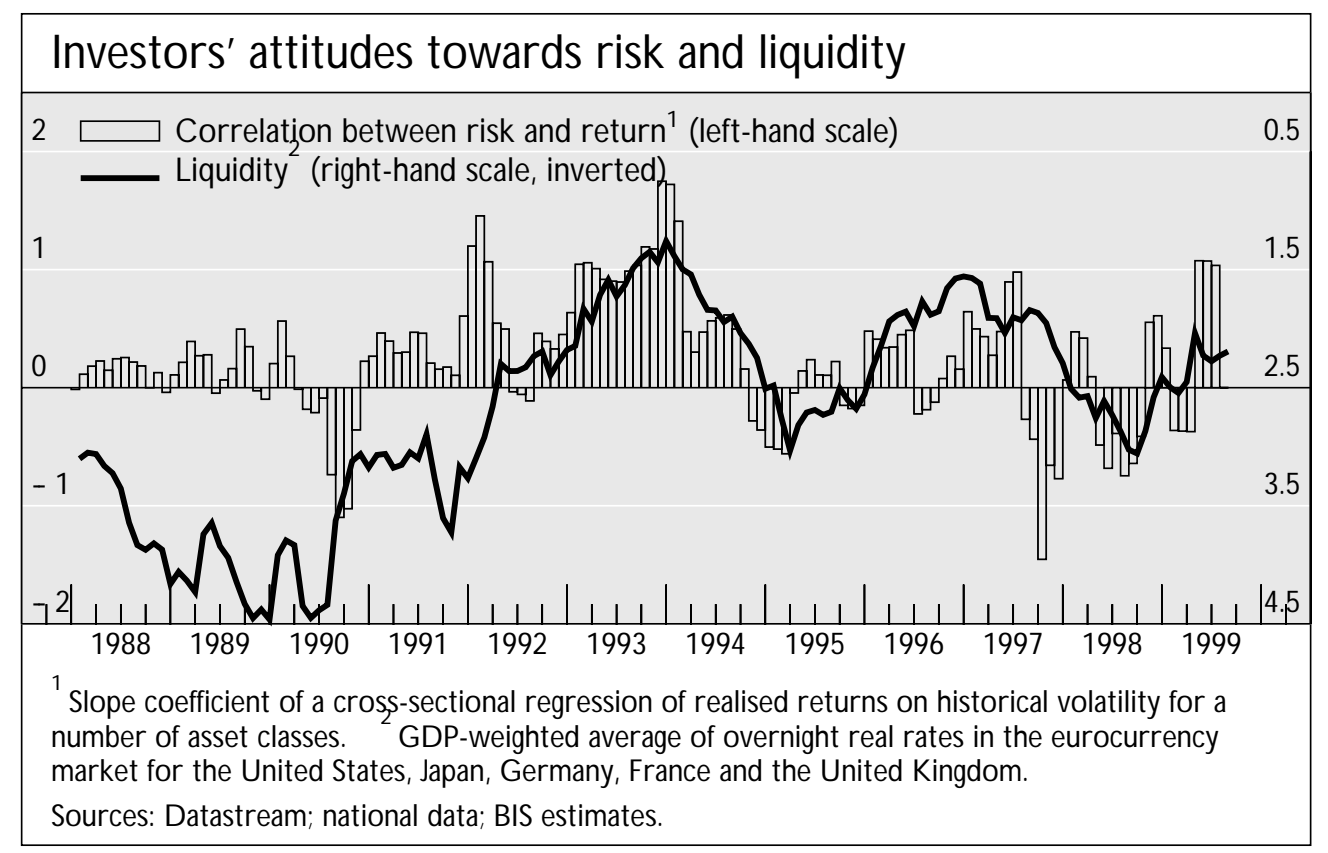

Concerning the possible contribution of monetary policies to asset price movements, nominal interest rates in the major industrial countries have come down sharply over the last decade. While real rates have not fallen much, ${ }^{14}$ investors suffering from money illusion may have believed they did. Chart 7 indicates how rapidly broad money has been growing (also relative to nominal income) in the G7 industrial countries. Moreover, it should be remarked that the discrepancy is most marked in recent years and that it has been growing in the United States in particular. This having been noted, recent empirical work has not been very successful in finding close relationships between such financial variables and asset prices. ${ }^{15}$

Yet, one cannot help but be struck by the fact that, over the last 15 years, financial conditions have been unusually easy in at least one major financial centre at all times. In the mid-1980s, the cost of capital in Japan was reduced to virtually zero as the US authorities demanded measures to stimulate demand growth in Japan, while the Ministry of Finance refused to countenance fiscal easing. In the

\footnotetext{
13 A similar conclusion seems implied by work recently published by JP Morgan (1999, Aug 25).

14 See IMF (1999) Box 4.1.

15 Ibid. Also see Philips and Drew (1999).
} 
early 1990s, real interest rates were very low in the United States as efforts were made to resist the "headwinds" generated by previous financial excesses. Moreover, this also contributed to a sharply lower dollar and a massive expansion of investment in Asian countries then pegged to the dollar. And more recently, the difficulties of the Japanese banking system have again led to virtually zero policy rates, significant uncovered borrowing in yen, and potential effects on currency values and asset prices in other countries.

\section{Chart 7}

Globally aggregated * money growth and short-term interest rates

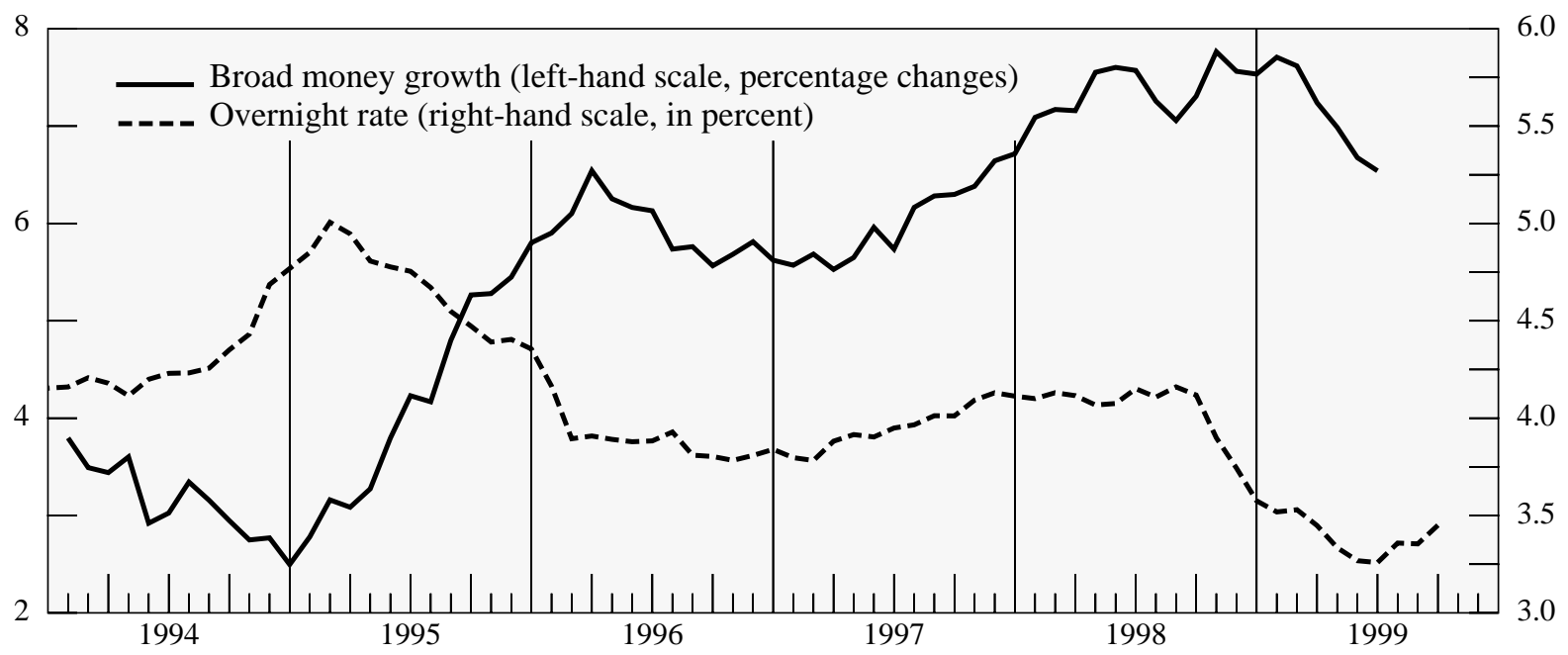

* Weighted average of the United States, Japan, the United Kingdom and the euro area.

Turning now to a possible private sector contribution to recent developments in international financial markets, Chart 8 does seem to indicate that investors in markets and institutional lenders have in recent years been pricing risk rather more aggressively than in the past. ${ }^{16}$ Equity prices in many countries are certainly difficult to explain using traditional investment criteria, as indicated by Chart 9 . If the price of financial assets is being pushed up, even as excess capacity is driving down the rate of return on the underlying assets, this is not a permanently sustainable situation. Moreover, credit spreads across sovereign members of the euro zone appear to give much less emphasis to different debt levels than has traditionally been the case in differentiating between Canadian provinces. ${ }^{17}$ Indeed, in the last year or so, the yield differentials in Canada have also narrowed significantly. It remains to be determined whether this latter development will prove permanent, indicating European developments have not been aberrant, or whether it indicates that the expanded appetite for risk has simply spread to Canadian markets.

Also see Kamin and von Kleist (1999). Another indicator of the appetite for credit risk is the ratio of yields on Baa to Aaa bonds. This measure seems to have been trending down through the 1990's.

17 See McCauley and White (1997) pp 12-15. 


\section{Chart 8}

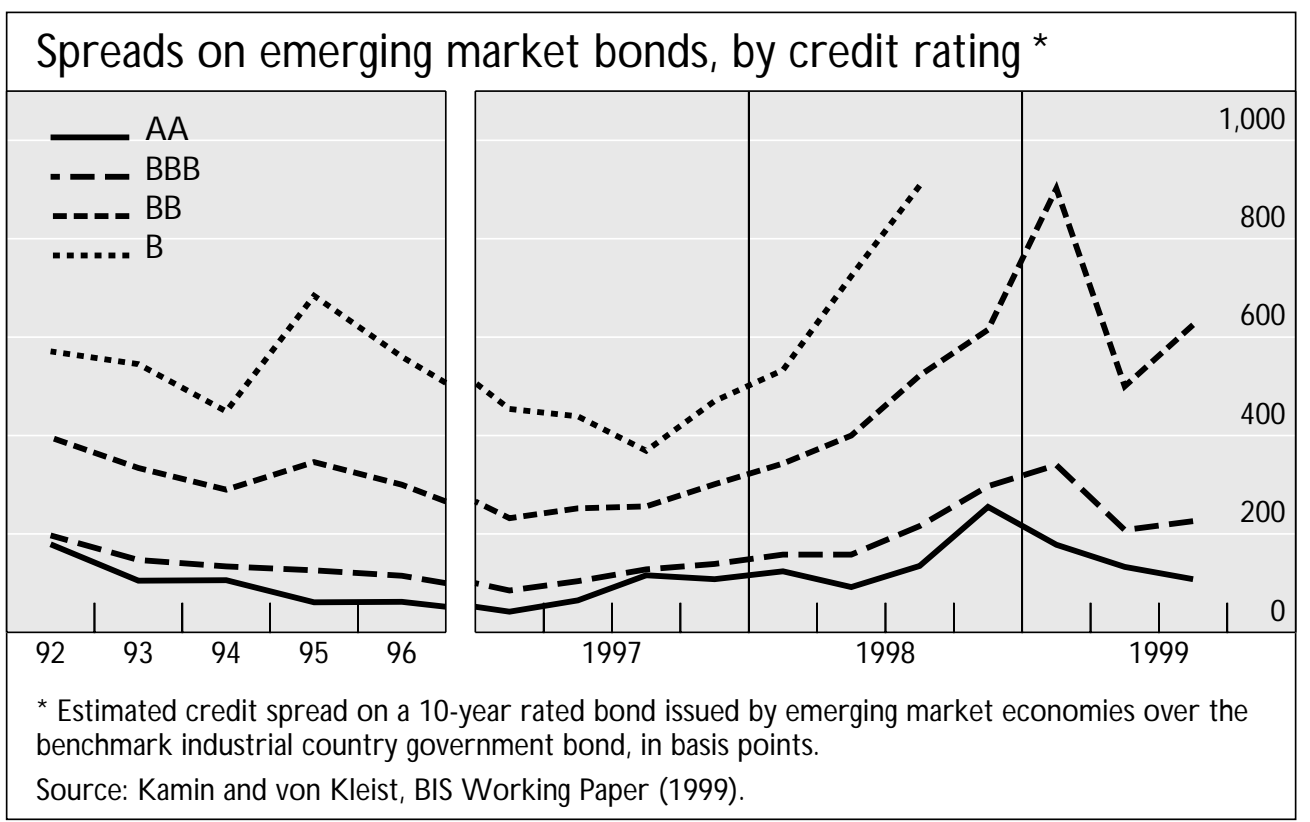

Chart 9

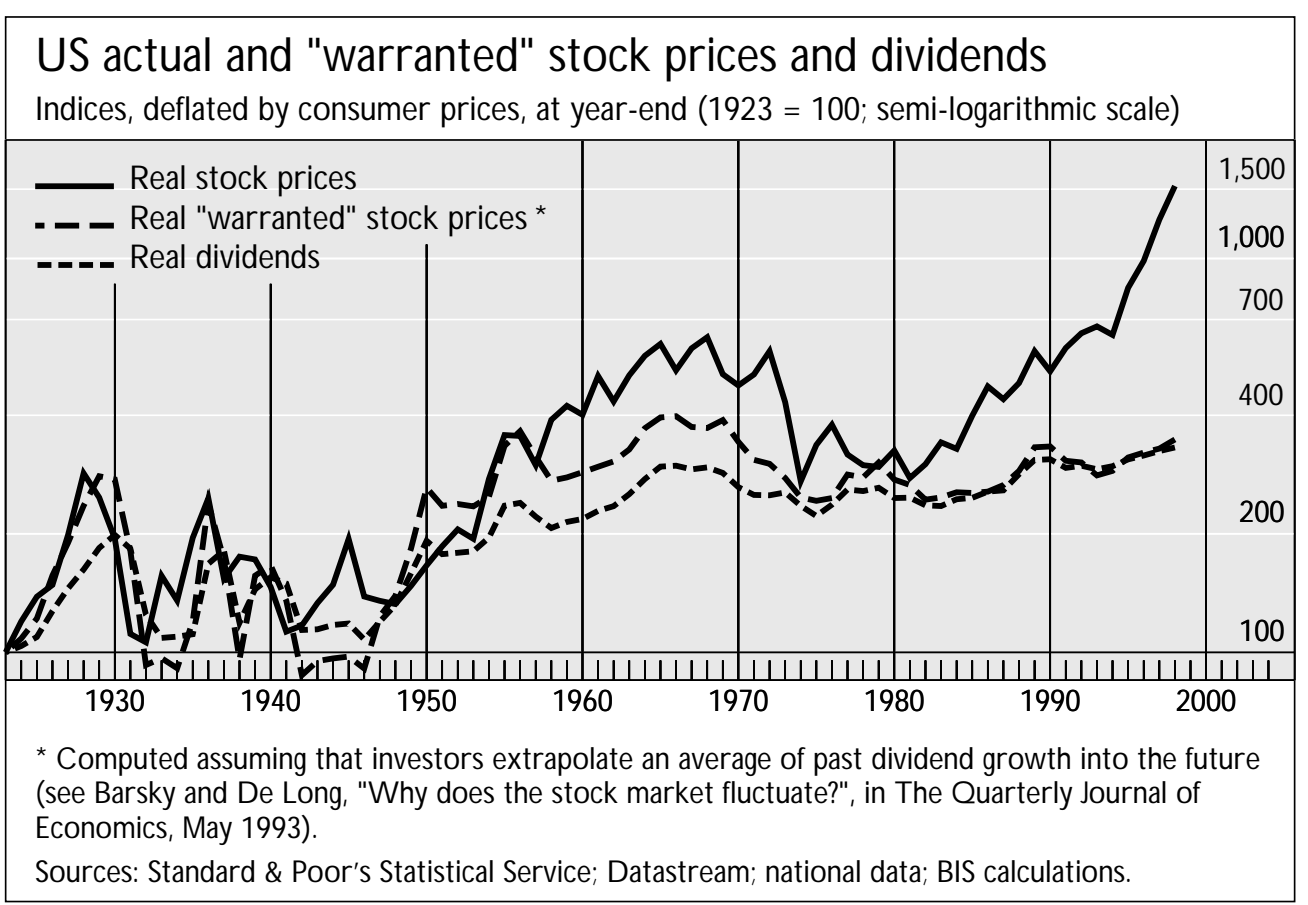

The behaviour of financial institutions in recent years seems to reflect two basic causes. ${ }^{18}$ One is that competition in the financial services area has increased markedly in recent years. Moreover, even as profits have been harder to come by (see Chart 10), the growing concern for shareholder value (especially in Europe) has meant that managers have come under substantially greater pressure to maintain or even expand profit levels. These developments in themselves might have inclined some

18 For a description of the global, as well as distinctively European factors at work (including the euro), see White (1998b). 
financial institutions to engage in riskier endeavours. Closely related to this has been the role of public safety nets, which have tended to attenuate perceptions of the possible costs associated with such risk taking. Consider, for example, the massive expansion of interbank lending to Korea at very short maturities prior to 1997. Explicit sovereign guarantees meant there was a perception of no credit risk. The fact that the loans were denominated in hard currencies and of short maturity led to the belief that there was no market risk. And, after the IMF interventions surrounding the Mexican and early Asian crises, liquidity risk may also have been considered minimal.

\section{Chart 10}

\section{Long-term accounting indicators of banks' performance}

$$
\begin{array}{ll}
\text { United States } & \text { Euro area } \\
\hline \ldots-\text { Japan } & \text { - }
\end{array}
$$
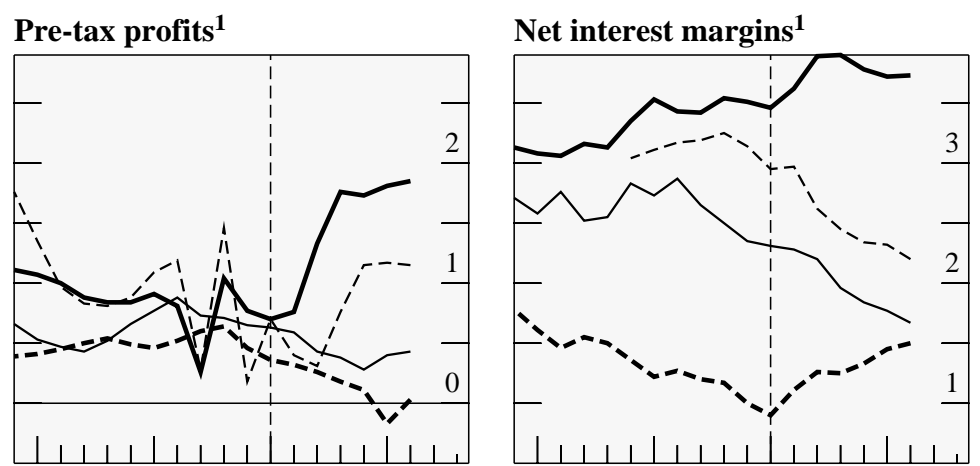

Loan loss provisions ${ }^{1}$

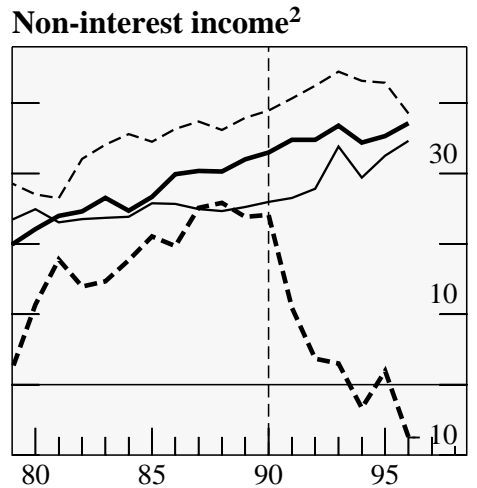

Operating $\operatorname{costs}^{2}$

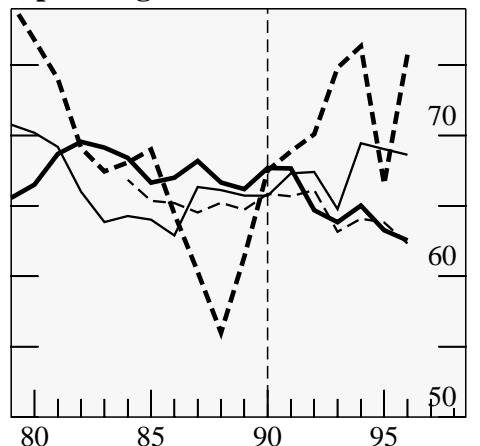

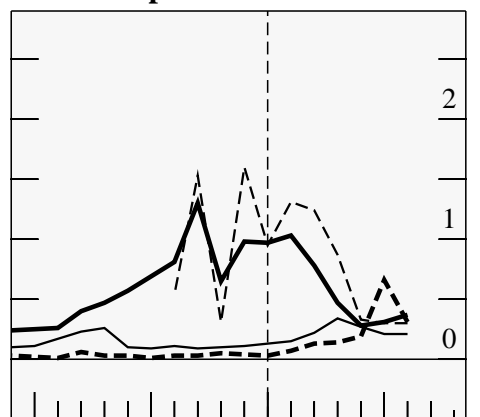

Staff costs ${ }^{2}$

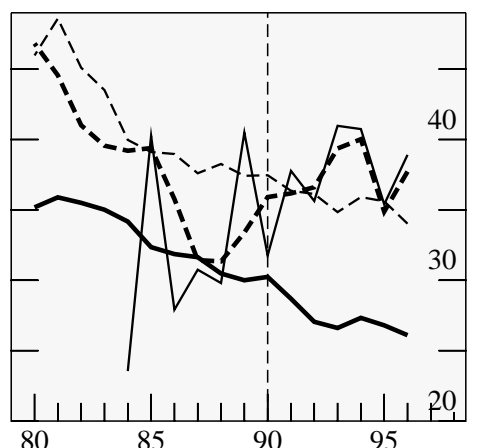

${ }^{1}$ As a percentage of average total assets (current and previous year). $\quad{ }^{2}$ As a percentage of gross income. Source: OECD.

What may have been the implications of these financial sector developments over the last number of years? Arguably, the first result has been the sharp expansion of the capital stock in a large number of specific industries worldwide: steel, shipbuilding, automobiles, chemicals, pharmaceuticals, electronic products, and commercial property in many emerging markets. ${ }^{19}$ It should be noted, moreover, that in some other industries new capacity is only just coming on line. ${ }^{20}$ It is this excess capacity which has

19 Other contributing factors have certainly been deregulation with respect to FDI in many emerging market economies and lower communication costs which have encouraged global "out-sourcing".

20 A recent article in the Financial Times stated that international telecommunication capabilities will in the next few years be a multiple of the most optimistic current assessments of future demand. 
driven down the prices of such products and materially aided the global process of disinflation which has been so welcome to date.

The problem of course is that the profits in these sectors are also under severe pressure meaning that loans taken out to finance capital expansion often cannot be repaid. This in turn threatens the viability of lenders in many cases. While the focus above has been on international financial markets, it should not be forgotten that domestic financial markets have also contributed materially to these developments. In Asia, for example, by far the largest portion of the credit granted during the boom period came from domestic sources (Table 2). As is now well known, many of the banking systems in many emerging markets now need significant restructuring as do their corporate structures. Such tasks are not easily accomplished ${ }^{21}$ and in the interval the affected economies may be subject to the significant headwinds arising from credit rationing. ${ }^{22}$ A second effect of a period of overinvestment is likely to be a sharp fall in overall demand as capital adjusts downward to desired levels. This is already evident in South-East Asia and Japan but the United States may also be somewhat exposed. The IT industry has made an extraordinarily large contribution to US output growth during this last cycle and the relative share of different kinds of investment spending has also been most unusual. ${ }^{23}$

Table 2

Bank borrowing from foreign banks in emerging market countries ${ }^{1}$

\begin{tabular}{l|c|c|c|c|c|c|c}
\hline & \multicolumn{3}{|c|}{ In \% of domestic credit } & \multicolumn{4}{c}{ Stocks in billions of US\$ } \\
\cline { 2 - 8 } & $\mathbf{1 9 9 0}$ & $\mathbf{1 9 9 7} \mathbf{Q 2}$ & $\mathbf{1 9 9 9} \mathbf{Q 1}$ & $\mathbf{1 9 9 0}$ & $\mathbf{1 9 9 7} \mathbf{Q 2}$ & $\mathbf{1 9 9 8}$ Q2 & $\mathbf{1 9 9 9}$ Q1 \\
\hline Indonesia & 11 & 18 & 41 & 5 & 25 & 18 & 17 \\
Korea & 16 & 29 & 19 & 21 & 92 & 61 & 56 \\
Malaysia & 14 & 25 & 23 & 4 & 25 & 19 & 18 \\
Philippines & 75 & 26 & 29 & 6 & 12 & 10 & 9 \\
Thailand & 17 & 46 & 28 & 8 & 86 & 55 & 40 \\
Argentina & 90 & 23 & 22 & 11 & 13 & 16 & 15 \\
Brazil & 37 & 25 & 33 & 28 & 50 & 59 & 47 \\
Chile & 29 & 10 & 9 & 4 & 4 & 4 & 4 \\
Mexico & 40 & 33 & 28 & 13 & 19 & 19 & 19 \\
CIS & & & & & & 44 & 38 \\
\hline
\end{tabular}

1 Measured by assets of BIS reporting banks vis-à-vis banks in countries listed above. ${ }^{2}$ Armenia, Azerbaidjan, Belarus, Kazakhstan, Kyrgyz Republic, Moldova, Russian Federation, Ukraine.

21

See Bernanke (1983) for a description of how uncertainty about the health of both lenders and borrowers can have effects greater than the sum of the parts.

23 The overall level of investment in the United States has been relatively strong, but much less than might have been expected on the basis of Tobin's Q ratio. Since replacement costs are now so low relative to purchase costs in the equity markets, one might have expected "more build and less buy". Perhaps both share buybacks and the expansion of merger and acquisition activity are better explained in terms of perceived near term effects on stock prices (and the effects on the values of managers' options) and the beneficial effects of "pooling of interests" accounting. To deal with this latter problem in the US, FASB wishes to treat all acquisitions as purchases and not mergers. 
Table 3

International bank and securities financing of emerging market economies

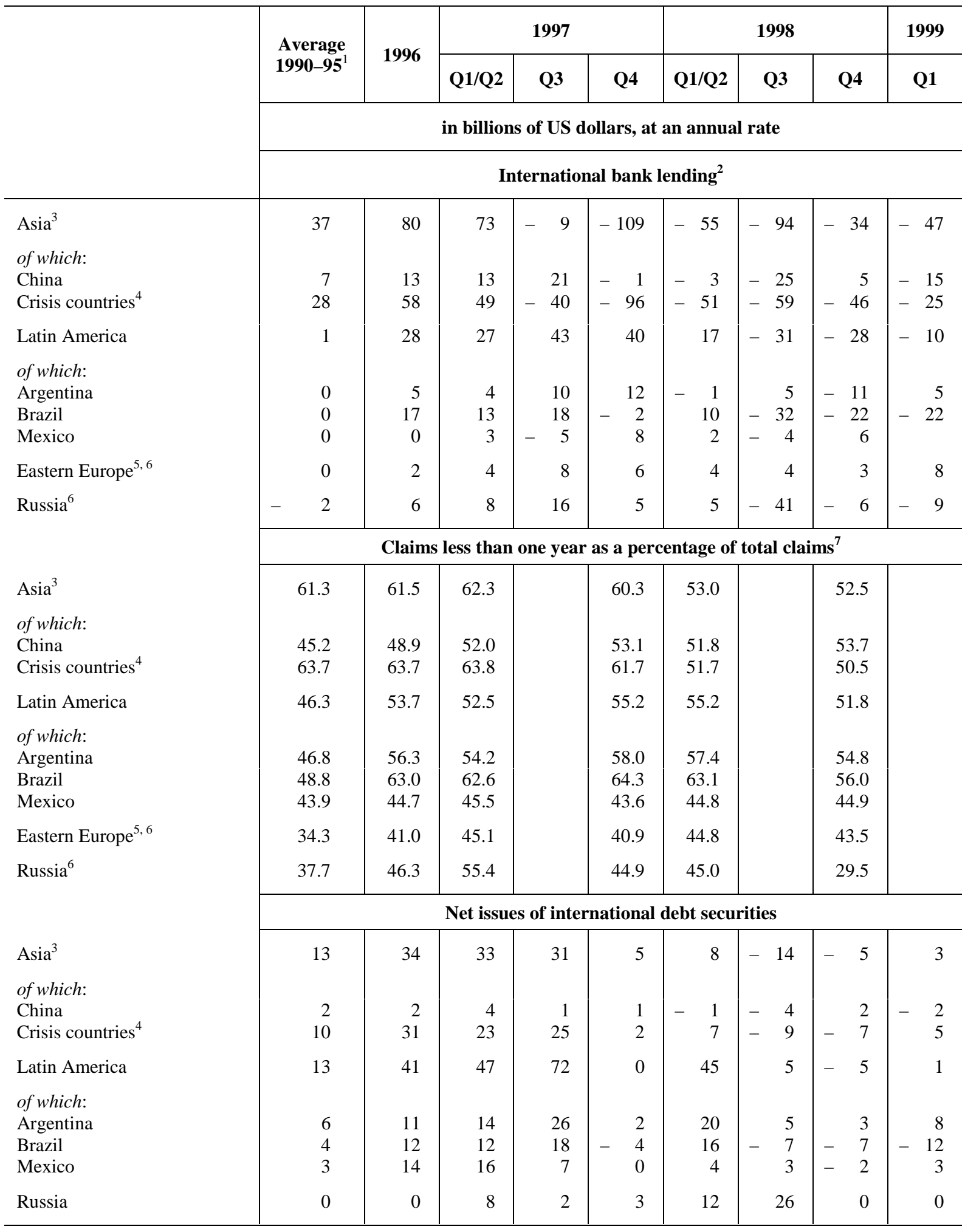

11993 Q4-1995 for net securities issuance. ${ }^{2}$ Exchange-rate-adjusted change in claims of BIS reporting banks. ${ }^{3}$ Excluding Hong Kong and Singapore. ${ }_{4}^{4}$ Indonesia, Korea, Malaysia, the Philippines and Thailand. ${ }_{5}^{5}$ The Czech Republic, Hungary and Poland. ${ }^{6}$ Data are available only from $1994 .{ }^{7}$ BIS consolidated statistics.

Source: BIS. 
A greater willingness to take on risk may also have contributed to the sharp pickup in capital flows to emerging market economies during the 1990's. Table 3 is instructive. In addition to showing the growing use of securities issuance, prior to the last quarter of 1997, it also makes clear the brutality of the turnaround when concerns about the riskiness of investments in emerging markets finally began to reassert themselves. It is worth noting, moreover, that the vast bulk of bank lending was first provided by Japanese banks, and then more recently by continental European banks. In both cases, albeit to varying degrees, domestic profits were under significant pressure at the time and government safety nets were commonly expected to be available. ${ }^{24}$ Moreover, if capital flows contributed to expansionary excesses on the way in, they also contributed significantly to crisis and recession on the way out. ${ }^{25}$ As external financing disappeared for Asian countries with sizeable current account deficits, domestic absorption had to be reduced by whatever amount was necessary to respect the underlying accounting identities. Indeed, as even trade credit dried up for some countries, the offsetting competitive advantages provided by a lower currency value could not be immediately exploited. ${ }^{26}$ This precedent also makes the current combination of recession and still large current account definite in many Latin American countries worrisome.

The last possibility to be considered is that international financial markets contribute to instability by increasing contagion across markets and countries that were previously more insulated. As for financial markets, there can be little question that they are now much more interrelated than a decade ago. ${ }^{27}$ However, what is not clear is whether this is a good or bad thing. On the one hand, individuals now have many more ways to cover risks, and there is the possibility as well that shocks may become dispersed across markets and therefore less harmful. During the events surrounding the LTCM crisis, for example, there was a very sharp reduction in the amount of international bank credit extended to non-bank customers (especially highly leveraged institutions), an associated unwinding of positions in derivatives markets, and also a flight by depositors to banks of the highest quality. In the face of these massive strains, the interbank deposit market expanded significantly and thus helped cushion the shock. ${ }^{28}$ On the other hand, it cannot be ruled out that a single market or piece of the underlying infrastructure (especially payment and settlement systems) might fail with knock-on effects of

24 In most instances the guarantees were implicit, but in such cases as the German Landesbank they were explicit.

25 Japanese banks financed their overseas investments by large scale borrowings on international capital markets through the early 1990's. This leveraging process has now gone sharply into reverse.

26 It is common to assume that real depreciation leads to expanded production of domestically produced goods and services via substitution effects. However, terms of trade effects and the need to service external debts denominated in foreign currency work (in some cases overwhelmingly) in the opposite direction.

27 A number of papers presented at the 1999 Autumn Economists Meeting at the BIS showed the extent to which the level of volatility of equity and bond prices in Europe and Japan seems to respond "excessively" to impulses arising in US markets. See BIS (forthcoming): "International financial markets and the implications for monetary and financial stability”, BIS Conference Papers, No. 8.

28 See BIS (1999b), Chapter VIII. 
significant magnitude. Moreover, as consolidation in the financial services industry leads to a smaller number of firms exercising greater influence over a diverse set of markets, the chances of spillovers that are unwarranted and potentially dangerous also increase. ${ }^{29}$

\section{Chart 11}

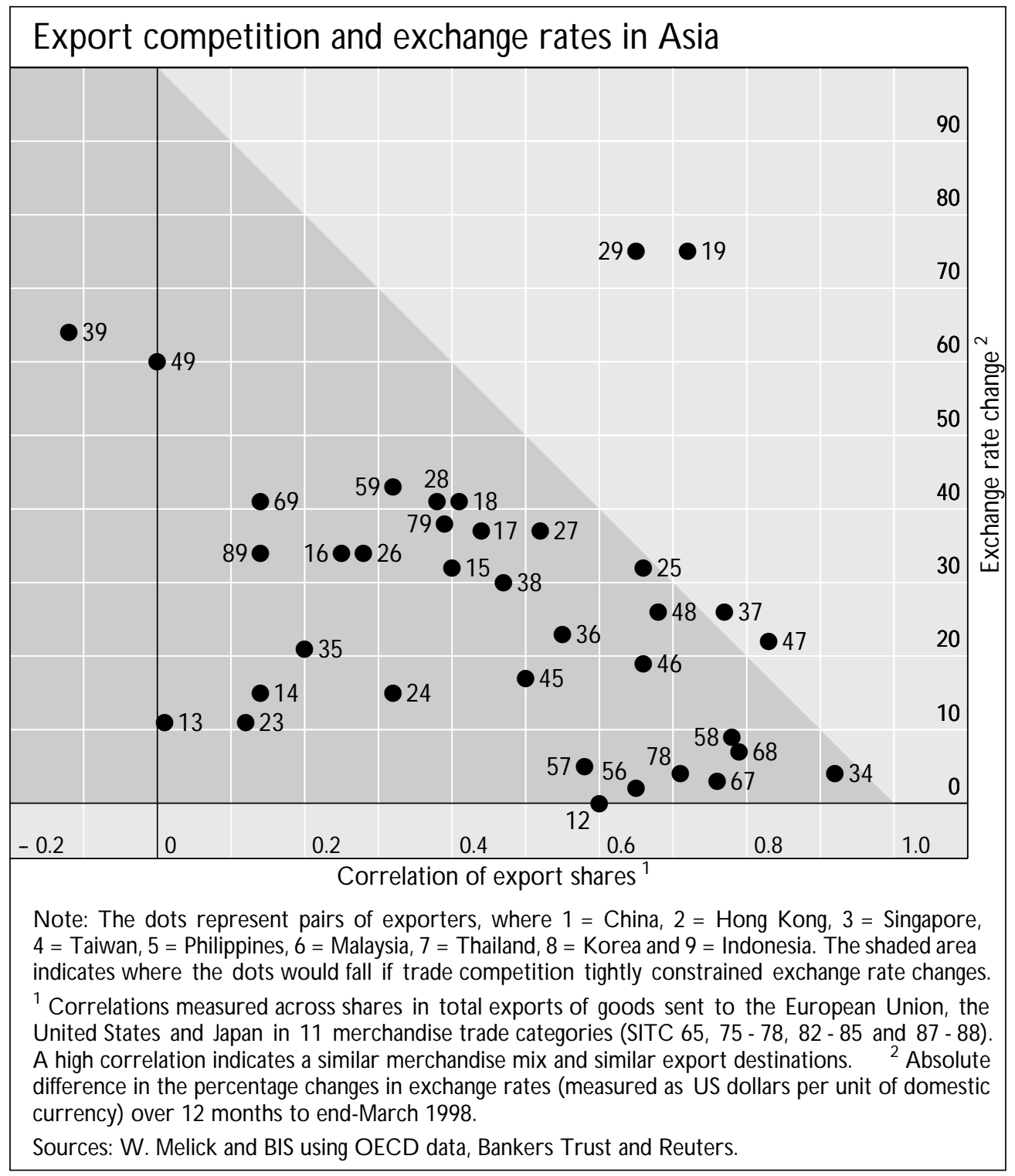

The problem of cross-country contagion, caused by the behaviour of lenders on international financial markets, received considerable attention during and following the Asian crisis. There is an element of truth in these allegations. ${ }^{30}$ Sometimes losses in one market forced liquidations in others, and sometimes withdrawals by retail investors forced generalised liquidations. It is also the case that some

The danger of such unwelcome dynamics will increase to the extent that the behaviour of big players can be observed and emulated by others. This was a problem during the LTCM crisis. The underlying problem is developments which encourage herding behaviour in financial markets.

30

See BIS (1998a), Chapter VI. 
investors relied rather mechanically on historical correlations of cross-country rates of return; thus pressure on one currency led to sales of another. As well, liquidity at times dried up in one market, leading investors to cover by selling in other markets (proxy hedging) which were still liquid. Finally, it may be the case that there was a generalised flight from risk which did not take into account the different circumstances of different countries.

Yet, it was also the case that the crisis-affected countries in Asia shared many similar characteristics. A sudden recognition of this reality might imply correlation but not contagion (White, 1998c); that is, difficulties in one country might have catalysed developments in another country but could not be said to have caused them. Shared domestic shortcomings included excessive capital formation, many bad loans and weak banking systems. Shared international characteristics included the fact that these countries were strong competitors with each other in export markets, which meant that currency depreciation on the part of one contributed materially to the pressure on others (Chart 11). Moreover, it is a fact that many of these countries were quite heavily dependent on the exports of electronic products whose prices were under severe downward pressure at the time. This was a further common shock.

Finally, and worthy of some special attention, all of the affected countries had in effect pegged their currencies to the US dollar in order to benefit competitively as the dollar fell against the yen prior to the spring of 1995. Many domestic investors believed that the peg would be held indefinitely and thus borrowed unhedged in foreign currency to get the benefit of much lower rates of interest. ${ }^{31}$ When the dollar subsequently began to rise sharply, and the effects of the earlier effective depreciation of the Chinese renminbi began to be felt, competitive pressures intensified and current account deficits widened in most countries. When the peg eventually had to be given up in Thailand, those who were short dollars suffered severely and this served to highlight the dangers facing those similarly exposed in other countries. As these people tried to cover themselves, they put downward pressure on their own currencies, contributing in turn to the wave of depreciations observed during that period.

\section{Strategies for preventing financial crises}

The thrust of the above comments is that financial instability has a number of manifestations: volatility, misalignments and contagion. Each may have a number of underlying causes, and it is important to know what they are before suggesting how problems might be rectified. Macroeconomic forces, some domestic and some international, have certainly contributed to recent and perhaps

31 Foreigners, including many hedge funds, did the same by buying Asian currencies forward on the expectation that they would depreciate less than was implicit in the interest rate differentials. 
prospective difficulties. However, deficiencies in the operation of financial systems (again at both domestic and international levels) have also had an unwelcome influence.

\subsection{An international superregulator?}

Some commentators have recently suggested the potential merits of an international superregulator to set standards, oversee international financial markets and impose discipline on those who seem to be behaving in ways inconsistent with international financial stability. ${ }^{32}$ Arguments in support of such a proposition include the globalisation of financial markets, the breakdown of sectoral distinctions worldwide (e.g. between banks, investment dealers, insurance companies and asset management firms), the growing integration and complexity of international financial markets, and the need for efficient information sharing by all relevant bodies. All of this would seem to argue for an organisation capable of seeing the big picture, and then doing something about it. In sum, this proposition would seem to be both comprehensive and fundamentally international, two of the underlying principles suggested above as being necessary for any strategy for fostering international financial stability.

The principal arguments against the proposition are both practical and political. At the practical level, oversight and supervision must be a very hands-on affair. This was one of the arguments used in Europe when it was decided that banking supervision would stay at the national level rather than migrating to the European Central Bank. Still more practically, one could ask whether the magnitude of the task faced by a single agency might be so great as to be effectively unmanageable. One is reminded that, in writing computer software, it is common to eschew seamless integration in favour of modular development. While the latter may be conceptually less efficient, it is also less likely to be a complete failure.

The political objections to this idea at the current time would seem significant. A superregulator with effective powers to set standards and enforce them globally would be enormously powerful. One could argue, at the level of principle, that national legislators are not yet ready for this. Consider how very similar arguments led to banking supervision being taken away from the Bank of England once it had been given "independence" in the conduct of monetary policy. Nor do national legislators seem ready to cede the degree of sovereignty that would be needed to make such a superregulator effective in practice. Consider, for example, the current Congressional antipathy to the International Monetary Fund and the typical difficulty of obtaining legislation to raise Fund quotas. Consider as well the application of the principle of subsidiarity in the European Union. And, finally, consider the protective attitude taken to their national financial sectors by governments in most countries of the world. It is

32 See Eatwell and Taylor (1998) and Currie (1999). 
true that all of these attitudes should and likely will change with time. But that seems more for the future than for now.

Another argument against this superregulator approach is that it could violate the second and third principles laid out above for choosing a strategy for promoting financial stability. These principles state that internal governance and market discipline should be at the heart of financial oversight, with the supervisory apparatus playing a complementary and market-consistent role. A superregulator could of course operate in this fashion, but the theory of bureaucracies teaches us that it might well be tempted to act in its own interests instead. That might imply growing recourse to traditional directives (and the need to police them) and less reliance on market processes.

A final set of points has to do with the difficulty of getting international agreement on the mandate, powers and accountability process of an international superregulator. Even more difficult: would it be possible to change these agreements in the light of changes in objective circumstances? The history of the United Nations and the Bretton Woods institutions teaches us that these are not unimportant issues. All of this perhaps argues for a more informal and "bottom up" approach to the promotion of financial stability.

\subsection{An incrementalist approach?}

\subsubsection{Issues of process affecting international financial stability}

The process already under way to enhance the prospects of international financial stability should be maintained and improved. This process is based on a piecemeal identification of shortcomings in all the areas discussed above, with attention then being paid to effecting improvements in individual areas. The latter challenge involves identifying what needs to be done and then actually implementing these recommendations. Also consistent with a "bottom up" approach is the idea that recommendations for change and for international standards should most properly arise from committees and working groups comprised of senior officials from the national capitals where sovereignty still resides. ${ }^{33}$ Judging from what has been accomplished to date, this approach seems to adhere to all four of the principles which should underlie any strategy chosen to foster international financial stability.

The identification of international problems affecting financial stability was for a long period the preoccupation of the various committees working under the aegis of the Group of Ten. Among those

33 Exceptions to this general rule, which was recommended in BIS/IMF (1997) and agreed to by Governors and Ministers at a special meeting in Hong Kong, are codes for how officials themselves should behave. The IMF, as directed by the Interim Committee, has already drawn up a Code for Transparency in the Conduct of Fiscal Policy and has recently finalised a Code for Transparency in the Conduct of Monetary and Financial (implicitly, regulatory) Policies. 
committees, the three standing committees which meet at the BIS $^{34}$ have made a particular contribution over the years. The publication in 1997 of the Report of the Working Party on Financial Stability in Emerging Market Economies (involving many representatives from emerging markets) ${ }^{35}$ also served to move this process forward. In particular, this report recommended the establishment of standards of best practice in a number of areas affecting financial stability. After the publication of this report, the Governors of the G10 then asked their three standing committees to establish whether there were other areas as well (the "gaps" exercise) where international standards might be both desirable and practically feasible. These committees reported in the affirmative and also made specific recommendations for following up.

Subsequently, following up on a promise made by President Clinton at an APEC conference in 1997, three working groups with proportionally larger representation from emerging markets made still further recommendations with a view to increasing transparency and accountability, strengthening financial systems, and improving the resolution of international financial crises. ${ }^{36}$ These recommendations elicited further comments, which have subsequently been published, ${ }^{37}$ and provided the basis for a number of conferences sponsored by the official sector in the first half of 1999. This trend towards relying more on broader-based (global) groupings of officials has recently received further impetus with the establishment of the G20. This group will have the G8 as core members and will also include about a dozen other countries, most from emerging markets. ${ }^{38}$ As an ancillary development, it has also been agreed that the Interim Committee of the IMF will now be viewed as a permanent body entitled the International Monetary and Financial Committee (IMFC). Meetings of the IMFC will be preceded by meetings of Deputies with a view to making the meetings more fruitful.

All of these parallel developments raise important uncertainties pertaining to overlap of mandates, the time absorbed in discussions to date and how all of these groups are to be managed in the future. The fact that the advent of European Union and the establishment of the European Central Bank raise further questions about European representation in many fora is another complication. However, what remains evident is that, since the Mexican crisis of early 1995, an enormous number of suggestions have been put forward as to how international financial stability might be improved. Unfortunately,

34 Namely (see footnote 3) the BCBS, CGFS and the CPSS. The accomplishment of these Committees over the years are recorded in successive BIS Annual Reports under the title "Activities of the Bank".

35 See BIS/IMF (1997).

36 See BIS/IMF/OECD/World Bank (1998).

37 Comments on the Reports on the International Architecture (1999).

38 The Working Groups arising from the APEC promise were set up by a group of 22 Ministers and Governors, whose Deputies were first assembled by invitation of the American authorities at the Willard Hotel in Washington. This history led to developments in this area being known as the Willard process. The G22 was then expanded to the G26, to bring in the smaller members of the G10. The Working Groups published their recommendations but never formally reported to the body that set it up. The G20 group might be thought of as the heir to the Willard process but it is too early to be sure of this. 
the record of implementation has been rather uneven to date. For example, it was suggested as far back as $1996^{39}$ that international bond contracts should contain majority voting provisions and sharing clauses. Thus far, the industrial countries have not thought it appropriate to lead by example and this topic remains actively under discussion.

To be sure significant progress has been made in other areas. For example, the G10 countries have declared themselves willing to commit to a template for revealing their foreign exchange positions, with a view to encouraging emerging markets to do the same. Moreover, following the precedent set by the Basel Supervisors in drawing up the Core Principles for Effective Banking Supervision, similar guidelines either have already been promulgated or are in the process of being prepared covering the behaviour of both public sector and private sector entities. ${ }^{40}$ The challenge which remains, however, is to actually implement these international codes of good practice. This will not be easy given shortages of knowledgeable resources in both industrial and emerging countries and often political unwillingness to take steps that might prove personally costly. In effect, what is really required is institution building, which is likely to be a long and difficult task at best.

Fortunately, experience to date with the implementation of the Core Principles for Effective Banking Supervision gives some practical hints as to how to move forward. The Basel Committee on Banking Supervision has established a Liaison Group (whose emerging market membership is similar to that of the proposed G20) and is in close contact with regional groups of supervisors. Both directly and in association with these groups, the BCBS is vigorously advocating the implementation of the Core Principles. Peer pressure of this sort may well be intensified if needs be. The International Monetary Fund is preparing to regularly monitor compliance in the context of Article IV consultations, ${ }^{41}$ and the World Bank group will focus on supporting necessary training and structural reform. The private sector can also help by imposing market penalties on those countries deemed not to conform to the Core Principles ${ }^{42}$ and the requirements for regulatory capital might also be affected. ${ }^{43}$ Finally, consideration might have to be given to denying rights of establishment in major financial centres to financial institutions from countries where the Core Principles for Effective Banking Supervision are being inadequately applied. This eventuality was in fact foreseen as far back as the Basel Concordat (BIS: BCBS, 1975), which was updated in 1992 (BIS: BCBS, 1992). The fact that so many different

39 See Group of Ten (1996).

40 For a comprehensive list and description of such standards and principles, see the website of the Financial Stability Forum (www.fsforum.org).

41 A large pilot project is already under way. It is still an open question whether or not the Fund will announce publicly its assessment of whether a country is in compliance or not.

42 In this area of compliance, as in all others, the market can only impose discipline if it has adequate information as to what is really going on. Thus, the primacy of transparency as an objective.

43 See Council on Foreign Relations (1999), pp. 7-8. 
incentive systems for implementation are being suggested reflects the widespread belief among officials that no single approach is likely to be wholly effective.

Of course, adopting a portfolio of approaches has one major deficiency. Lacking specific accountability, those responsible for individual initiatives might pursue them with inadequate vigour based on the expectation that someone else might be counted on to act. In this regard, the recent establishment of the Financial Stability Forum may be a big step forward. For the first time, it will bring together representatives of international financial institutions, central banks, Treasuries and regulators at the international level. While established under the aegis of the G7, its membership was expanded in June 1999 to include four other countries with large financial sectors. ${ }^{44}$ Moreover, the Forum will identify the work that needs to be done, will set priorities in light of scarce resources and will monitor implementation. Finally, given the high level of the official participants, the Forum should be able to mobilise the political influence to ensure that hard decisions are actually taken when needed. In this context, the nature of the prospective relationships between the Financial Stability Forum, the G7 and G20 still needs to be assessed.

\subsubsection{Issues of substance affecting international financial stability}

In Section 3 above, problems of financial instability were classified as having to do with short-term price volatility, medium-term misalignments (including the problem of "excessive" international capital flows) and international contagion. Before considering below some policy recommendations that might serve to alleviate each of these problems, a more generic recommendation could be made. Continuing attention needs to be paid to monitoring international financial markets for signs of emerging stress. Given the speed with which crises can erupt, and spill over in modern financial markets, paying only sporadic attention to such possibilities would not seem prudent. In this regard, the renewed emphasis on regular monitoring in the CGFS and in other official fora is to be welcomed. So too should be efforts to improve the data on which judgements must ultimately rest. In this regard, significant deficiencies remain in the area of OTC derivatives and in the construction of comprehensive debt statistics for both emerging and industrial countries. As foreigners increasingly purchase domestic bond issues, and as international issues are increasingly purchased by nationals of the issuing country, the distinction between domestic and international bond issues is becoming less meaningful.

The dangers of excessive short-run price volatility, and at the limit the failure of markets to function, have been a longstanding source of concern. Serious problems associated with the failure of payment and settlement systems were only just averted in light of the failure of Drexel Burnham Lambert in 1988. In the event, spreads in markets where DBL had previously been very active widened

Countries named to date are Hong Kong, Singapore, Australia and the Netherlands. 
substantially. More recently, a different aspect of the problem came to the forefront during the events surrounding the Russian moratorium and the near-collapse of LTCM. The heart of this latter problem seemed to be high levels of leverage, not only by so-called hedge funds, but also by the proprietary trading desks of investment firms as well as others. Since many of these firms are unregulated, and since attempts to regulate them could simply drive them offshore, attention has shifted (for the moment at least) to other ways to approach this problem.

Three initiatives have been undertaken by the Basel community, each having a somewhat different objective. The Basel Supervisors ${ }^{45}$ have been concerned that bank lending to such entities could threaten the system by bringing down the banks, should the creditor default because of some market accident. Clearly, restraints imposed from the side of the lenders would also have effects on the capacity of borrowers to leverage themselves and thus indirectly on short-term market volatility. A working group set up by the Committee on the Global Financial System (the Fisher Group) is looking into what kinds of improvements in voluntary disclosure by large financial institutions of all kinds would be most effective in improving systemic stability. This reflects concerns that, in the absence of full information, lenders might suddenly refuse to deal with a large number of counterparties, aggravating short-run liquidity and related problems. Finally, another working group of the CGFS (the Patat Group) assessed whether it would be feasible to provide additional aggregate information on activity in currency markets. The aim would be to improve market stability by enhancing the capacity of market participants to identify the potential for large exchange rate movements and for contagion, especially in emerging markets. In the event, it transpired that it would not be possible to obtain adequately comprehensive and timely information on a voluntary basis, and legislative solutions were deemed impractical. ${ }^{46}$

Another insight arising from the sharp price movements experienced following the Russian moratorium was that commonly accepted risk management procedures may promise more comfort than they actually provide. Normally, credit risk, liquidity risk and market risk are thought of as separable and additive. However, during the events of last fall, these risks proved highly interactive with heightened concerns about credit risk causing liquidity to disappear, generating in turn price movements significant enough to have effects on perceptions of market risk. ${ }^{47}$ Indeed, commonly used measures of Value at Risk turned sharply upwards ${ }^{48}$ implying that firms with pre-committed

45

The supervisors have already published two studies on this issue. See BIS: BCBS (1999a and 1999b) and a follow-up document assessing the response of the banking community will be issued shortly.

The Working Group on Highly Leveraged Institutions, established under the Financial Stability Forum, has also set up a study group to assess the impact of the activities of HLIs on small and medium sized economies. See Financial Stability Forum (1999).

47 The CGFS has also conducted a series of studies into the nature of liquidity in financial markets and market behaviour under stress. See BIS: ECSC (1997) and CGFS (1999a).

48

See BIS: BCBS (1999c). 
levels of economic capital were forced by their methodologies to retreat from exposed positions, even if they might have thought that prices had overshot. This behaviour may have amplified the original disruption, showing once again how sensible policies at the level of the firm can suffer from "fallacies of composition". The lesson from all of this is that "stress testing" needs to be relied upon more heavily, and that the implications for profits and losses of even highly improbable events need to be given serious consideration and capital requirements adjusted accordingly.

A final insight from recent events is that the institutional infrastructure may have implications for even the short term functioning of markets. Prices of contracts on organised exchanges were much less affected than the prices of OTC instruments, presumably because of greater liquidity in the former case. As well, European markets were not as greatly disrupted by the events in the autumn of 1998, perhaps because of the greater reliance put by borrowers on access to their traditional bank lenders. Even in the Unites States, the fact that many corporations had prenegotiated lines of credit with banks helped minimise the implications when their access to market funding suddenly dried up. These observations should not, of course, be taken as an endorsement of a bank-based system as opposed to a market based one. Recall that it was primarily bank lending (indeed mostly interbank lending) that accounted for excessive capital inflows into South-East Asia, and it was also imprudent bank lending that was at the heart of the LTCM crisis.

Measures to reduce the likelihood of medium-term misalignments (and problems associated with international capital flows) have both a macroeconomic and an institutional dimension. Consideration of the former issue raises some questions which were hotly debated in the 1920's ${ }^{49}$ and have resurfaced more recently. ${ }^{50}$ The fundamental question is whether monetary policy should be conducted solely with a view to controlling domestic inflation, as measured by some index (PGNP or $\mathrm{CPI}$ ) of the prices of currently produced goods and services. Or, rather, whether monetary policy should sometimes (perhaps rarely) pay more attention to asset price developments, particularly when they are associated with rapid credit extension and the related possibility that this could feed back on the health of the financial system. ${ }^{51}$ The presence of such other imbalances as trade deficits and/or heavy short-term exposure to foreigners might also be germane to judgements in this area. In passing, it can be noted that attempts to use "moral suasion" as a second instrument to help achieve two price targets simultaneously could not be guaranteed to work and might even have unwelcome side effects. ${ }^{52}$

49

The principal protagonists were Keynes and the Cambridge school on the one hand, and the Austrians (Hayek, von Mises, Robbins, etc.) on the other. See Cochrane and Glahe (1998).

50 For a discussion of many of the issues in a modern setting, see BIS (1998b).

51 In circumstances where CPI inflation was under control but asset prices were not, the choice might be to raise interest rates and undershoot the CPI target a little, or wait until the bubble had burst and then undershoot more significantly.

52 A failed attempt to talk down the market might be interpreted as meaning that the authorities had no capacity to resist further price increases. This might then lead prices to rise even further. This is arguably what happened after Allen 
One could also ask whether domestic monetary policies should not sometimes be influenced by international considerations going beyond the influence of the exchange rate on domestic prices. ${ }^{53}$ The willingness of the Federal Reserve to lower interest rates in the autumn of 1998, when other indicators might have pointed towards tightening, seems consistent with the hypothesis that downside risks on the international side may sometimes have an independent influence. In contrast, consider the expansionary monetary policies followed in the United States in the early 1990's. This policy was pursued even though it contributed to an unwelcome tightening of monetary conditions in Japan, as the Yen strengthened significantly during a deep recession. This effect was viewed more traditionally as being one for the Japanese authorities to deal with, using the domestic policy instruments they had available. Whether greater attention will have to be paid to the exchange rate implications of domestic policy changes in a world of three (or perhaps only two) large currency blocks seems likely to be a topic for ongoing debate.

Dealing with the sporadic tendencies of lenders to underprice risks of all sorts is not an easy problem to deal with through institutional reform. To the degree that this tendency is heightened by exacerbated competitive pressures, care should be taken to ensure that deregulation does not proceed at a faster pace than is compatible with good supervision and regulation. To the degree that this tendency is also exacerbated by safety net considerations, these should be systematically reviewed. In this context, it is important to note that there is a clear trade-off between safety net provisions which help manage crises today and the likelihood that associated moral hazard will create even bigger crises tomorrow. The existence of this trade-off leads to the conclusion that the practical design of safety nets is an important issue, and one made more complicated by the realisation that safety net provisions can also interact in complicated ways. ${ }^{54}$ Recognising that regulatory provisions can have systemic implications with macro-economic effects, raises two further questions. ${ }^{55}$ Should central banks have a role in helping design regulatory regimes, and should they have some advisory role when it comes to enforcement? In many countries there now seems to be a significant degree of uncertainty about the respective roles of central banks and other agencies in promoting financial stability.

Greenspan, Chairman of the Federal Reserve Board, spoke of "irrational exuberance" in the U.S. stock market, even though close attention to his text indicates he did not in fact make a statement about price levels themselves. Rather, he was noting the absence of a methodology for determining when such irrational exuberance might exist.

53

Even within this traditional framework, large movements in the exchange rate can complicate monetary policy judgements. As the exchange rate strengthens and disinflation proceeds in consequence, policymakers have to decide how much of this disinflation will have to be given back should the exchange weaken under the influence of a deteriorating current account.

For example, the need for deposit insurance may be attenuated by the design of exit policies. Assuming that the information provided to regulators is correct, a process of Structured Early Intervention and Resolution (as in FDICIA in the US) might imply no need for deposit insurance at all.

55 For a further discussion, see White (1999), pp. 24-6. 
Even assuming that biases in the incentive structures affecting lenders could be removed, mistakes would still be made. This implies that greater attention must be paid to internal governance and adequate risk management systems. A second pillar should be market discipline, and a third pillar should be adequate external supervision. Note that this ordering is quite different from what would have been the norm twenty years ago. For all of these governance processes to work effectively, the sine qua non is transparency about what is actually going on. Obviously, this need for transparency relates to the activities of financial institutions themselves but it also extends to the activities of their clients. And finally, if there is to be transparency, there must be some common understanding about accounting procedures and definitions. For governance purposes, good accounting standards are the essential building block, and such standards are not always in evidence even in some parts of the industrial world.

As for the related issue of international capital flows, solutions must balance off longer run concerns about allocational efficiency against shorter run concerns about macroeconomic disruptions. In the last year or so, perhaps for obvious reasons, ${ }^{56}$ the balance has shifted somewhat and market based approaches to dissuading short term capital inflows now seem more generally acceptable. There is also greater recognition of the fact that existing controls should be dismantled more carefully, particularly if (as is often the case) the domestic financial system is not very sound. While there appears to be a growing consensus that new controls on inflows should be market based, temporary and focussed more on short term inflows, it is also becoming increasingly recognised that the availability of derivative instruments invites arbitrage across categories when controls are not broadly based. As for imposing new controls on capital outflows, a general sense of antipathy continues to prevail, tempered by a willingness to study more carefully the recent Malaysian experiment. Of course, this experiment would have had a quite different outcome had the Malaysian example generated fears of similar actions in other countries and given still further impetus to capital flight.

Countries which do wish to maintain a liberal regime with respect to capital flows should also plan for the possibility that rapid inflows could turn into equally rapid outflows. Since these flows are small when viewed from the perspective of foreign lenders, as well as those that supervise them, the onus must fundamentally be on the borrower to protect himself. This could imply building up reserves as inflows accumulate and paying closer attention to maturity and currency mismatches in the national balance sheet as a whole. In this context, the greater emphasis being put by the IMF and World Bank on developing some principles for prudent debt management in developing economies is to be welcomed. ${ }^{57}$ Some have also suggested the possible usefulness of binding contingent lending facilities

56 As James Tobin once noted "It takes a heap of Harberger triangles to fill an Okun gap".

57 Some attention to this issue is also being paid by the FSF Working Group on Capital Flows. A conference on this topic was also held at the BIS in December 1999. See BIS (forthcoming): "Managing foreign debt and liquidity risks in emerging markets", BIS Policy Papers, No. 8. 
with the private sector to ensure financing (new money, rollovers, or maturity lengthening) in times of stress. Presumably such private sector agreements would be subject to a variable fee related to the assessment of risk, as well as monitoring by those providing the insurance. Both of these developments would seem to provide desirable incentives to prudent behaviour.

Turning finally to solutions for the problem of contagion across markets and countries, it is worth repeating the conclusion above that there remain uncertainties about the seriousness, although not the existence, of these problems. Market interrelationships are the source of many of the efficiencies provided by modern financial markets, and policies to minimise disruptive cross-market price movements would have to take care not to lose these efficiencies. A closely related observation is that, in many emerging market economies, there is a shortage of interrelated markets rather than an excess. In particular, the absence of well functioning domestic bond markets implies an unhealthy dependence on bank financing, and an equally unhealthy reliance on bond issues in international financial markets. All this having been said, the possible effects on market dynamics of any further concentration of market activity in the hands of a relatively few internationally active firms (particularly if they have similar trading strategies and risk management schemes) needs to be assessed. As for cross-country contagion, it was suggested above that this problem might be less serious than appears at first glance. Moreover, renewed inflows into emerging markets during 1999 do seem to reflect a heightened appreciation of differences in the circumstances of individual regions as well as individual countries. ${ }^{58}$ It was contended above that shared underlying problems also contributed to the appearance of contagion in Asia. In this regard, the biggest shared problem was excessive reliance on a fixed exchange rate system when capital inflows were heavy. The result of such policies was that the peg eventually had to be given up, but on the downside, in an environment of crisis rather than one of a measured response to changes in external circumstances. It is now commonplace to suggest that countries are being driven into corner regimes based either on currency boards or some form of managed floating. Without wishing to deny the merits of either alternative, it is also important to note that each requires certain preconditions and each has inherent shortcomings. ${ }^{59}$ In the absence of ideal solutions, choices will therefore have to be made on a case by case basis. ${ }^{60}$ 


\section{Final remarks}

Domestic financial markets have become much more liberalised in the last few years, and international linkages have also grown remarkably. The multiplicity of agents in financial markets, the complexity of the instruments being used, and the speed of change have brought many benefits in terms of more efficient provision of financial services and the more efficient allocation of credit. Moreover, such benefits translate over time into faster growth, more jobs and better jobs than would otherwise be the case.

However, what also seems to be associated with developments of this sort is a heightened tendency to financial instability and even sporadic crises. The challenge is to find some means of trading off these costs against the benefits. As indicated above, thinking about how to make the international financial system more stable has almost turned into an industry itself. However, it is notable that most of the thinking surrounding the search for a "New International Financial Architecture" has resulted (less grandly) in suggestions for only incremental changes to the current system. Moreover, it is now being increasingly recognised that implementation of even a limited number of these suggestions will be enormously challenging given the shortage of skilled resources in both domestic and international institutions. This reality underscores the need to set priorities and to ensure good cooperation among the number of groups active in this arena. 


\section{References}

Andersen, Palle (1997): "Forecast errors and financial developments". BIS Working Papers, No. 51, November.

Bank for International Settlements (BIS) (1996): "Financial market volatility: measurement, causes and consequences". BIS Conference Papers, Vol. 1, March.

BIS (1998a): 68th Annual Report, June.

BIS (1998b): "The role of asset prices in the formulation of monetary policy". BIS Conference Papers, Vol. 5, March.

BIS (1999a): Quarterly Review: International Banking and Financial Market Developments, March.

BIS (1999b): 69th Annual Report, June.

BIS (1999c): "Bank restructuring in practice". BIS Policy Papers, No. 6, August.

BIS (forthcoming): "International financial markets and the implications for monetary and financial stability”. BIS Conference Papers, No. 8.

BIS (forthcoming): "Managing foreign debt and liquidity risks in emerging markets". BIS Policy Papers, No. 8.

BIS: Basel Committee on Banking Supervision (BCBS) (1975): Report to the Governors on the supervision of banks' foreign establishments, 26 September.

BIS: BCBS (1992): Minimum Standards for the Supervision of International Banking Groups and Their Cross-Border Establishments, July.

BIS: BCBS (1999a): Banks' interactions with highly leveraged institutions, January.

BIS: BCBS (1999b): Sound practices for banks' interactions with highly leveraged institutions, January.

BIS: BCBS (1999c): Performance of models-based capital charges for market risk, September.

BIS: Committee on the Global Financial System (CGFS) (1999a): Market liquidity: research findings and selected policy implications, May.

BIS: CGFS (1999b): "A report by a Working Group of the CGFS on the events of the Fall of 1998". October.

BIS: Euro-Currency Standing Committee (ECSC) (1997): The Measurement of Aggregate Market Risk, November.

BIS/IMF (1997): "Financial stability in emerging market economies". Report of The Working Party on Financial Stability in Emerging Market Economies, April.

BIS/IMF/OECD/World Bank (1998): Summary of Reports on the International Financial Architecture, October.

Bernanke, B (1983): "Non-monetary effects of the Financial Crisis in the Propagation of the Great Depression". American Economic Review 173 (3): 257-76.

Cochran, John and Fred Glahe (1998): "The Drama: Hayek-Keynes Debate Over the Nature and Causes of the Business Cycle". Unpublished.

Council on Foreign Relations (1999): "Safeguarding Prosperity in a Global Financial System. The Future International Financial Architecture". Report of an Independent Task Force, published by the Institute for International Economics. 
Currie, Carolyn (1999): “The Need for a Supra-Mega Regulator for the Next Millennium - Is There Evidence?" Presentation at the Global Finance Conference, Istanbul, 7-9 April.

DeLong, J Bradford (1999): “Should We Fear Deflation?” Brookings Papers on Economic Activity, No.1.

Eatwell, John and Lance Taylor (1998): "International Capital Markets and the Future of Economic Policy: A proposal for the creation of a World Financial Authority". Mimeo (Ford Foundation).

Edwards, Sebastian (1998): “Abolish the IMF”. Financial Times, 13 November.

Financial Stability Forum (1999): Background Brief for the Press in connection with the $2^{\text {nd }}$ Meeting of the Financial Stability Forum on 15 September 1999.

Financial Times (1999): "Banks to improve risk management". 26 August.

Fischer, Stanley (1999): "Frequency of Global Crises Highlights Need to Consider International Lender of Last Resort". IMF Survey, January.

Garten, Jeffrey (1998): "Needed: A Fed for the World". New York Times, 23 September.

Group of Ten (1996): "The Resolution of Sovereign Liquidity Crisis". A report to the Ministers and Governors prepared under the auspices of the Deputies, May.

G22/Willard (1999): Comments on the Reports on the International Financial Architecture, August.

Kamin, S B and K von Kleist (1999): "The evolution and determinants of emerging market credit spreads in the 1990s". BIS Working Papers, No. 68, May.

International Monetary Fund (IMF) (1999): World Economic Outlook. Washington, September.

Martin, Bill (1999): “Liquidity traps”. Phillips \& Drew, August.

McCauley Robert N and William R White (1997): "The euro and European financial markets". BIS Working Papers, No. 41, May.

Morgan, JP (1999): "Valuing Market Liquidity”. JP Morgan Securities Ltd, 18 August.

Murray, John, Simon van Norden and Robert Vigfusson (1996): "Excess volatility and speculative bubbles in the Canadian dollar (real or imagined?)". BIS Conference Papers, Vol. 1, March.

Philips \& Drew (1999): “Does Liquidity matter?” Research Group Occasional Paper, No. 6, August.

Radelet, Steven and Jeffrey Sachs (1997): "What Have We Learned, So Far, from the Asian Financial Crisis?" Mimeo, Harvard Institute for International Development, January.

Soros, George (1998): “The Crisis of Global Capitalism”. Wall Street Journal, 15 September.

White, William R (1998a): "Promoting international financial stability: the role of the BIS", in Teunissen (ed.), Regulatory and supervisory challenges in a new era of global finance, Forum on Debt and Development (FONDAD).

White, William R (1998b): "The Coming Transformation of Continental European Banking”. BIS Working Papers, No. 54, June.

White, William R (1998c): "Crisis "contagion" in Asia: causes and preventive measures", in Swiss Journal of Economic and Statistics, Vol. 4.2, December.

White, William R (1999): "Evolving International Financial Markets: Some Implications for Central Banks. 



\section{Recent BIS Working Papers}

No.

68

May 1999

69

June 1999

70

June 1999

71

June 1999

72

August 1999

73

August 1999

74

August 1999

75

August 1999

76

October 1999

77

October 1999

78

October 1999

79

November 1999

80

November 1999

81

November 1999

82

November 1999

83

January 2000
Title

The evolution of determinants of emerging market credit spreads in the $1990 \mathrm{~s}$

Credit channels and consumption in Europe: empirical evidence

Interbank exposures: quantifying the risk of contagion

The term structure of announcement effects

Reserve currency allocation: an alternative methodology

The Taylor rule and interest rates in the EMU area: a note

The dollar-mark axis

A note on the Gordon growth model with nonstationary dividend growth

The price of risk at year-end: evidence from interbank lending

Perceived central bank intervention and market expectations: an empirical study of the yen/dollar exchange rate, 1993-96

Banking and commerce: a liquidity approach

Pass-through of exchange rates and import prices to domestic inflation in some industrialised economies

A note on alternative measures of real bond rates

Interbank interest rates and the risk premium

Sacrifice ratios and the conduct of monetary policy in conditions of low inflation

Switching from single to multiple bank lending relationships: determinants and implications
Author

Steven B Kamin and

Karsten von Kleist

Gabe de Bondt

Craig H Furfine

Michael J Fleming and Eli M Remolona

Srichander

Ramaswamy

Stefan Gerlach and

Gert Schnabel

Gabriele Galati

Henri Pagès

Craig H Furfine

Gabriele Galati and William Melick

Joseph G Haubrich and João A C Santos

Jonathan McCarthy

Palle S Andersen

Henri Pagès

Palle S Andersen and William L Wascher

Luísa A Farinha and João A C Santos 